\title{
ARTIKEL STRUKTUR DATA PENGERTIAN STRUKTUR DATA
}

\author{
Aris Suwandi \\ 175100054 \\ Universitas Mitra Indonesia, Sistem Informasi \\ arisuwandi.students@umitra.ac.id \\ ABSTRAK
}

\begin{abstract}
Dalam istilah ilmu komputer, sebuah struktur data adalah cara penyimpanan, penyusunan dan pengaturan data di dalam media penyimpanan komputer sehingga data tersebut dapat digunakan secara efisien.Sedangkan Data adalah representasi dari fakta dunia nyata. Fakta atau keterangan tentang kenyataan yang disimpan, direkam atau direpresentasikan dalam bentuk tulisan, suara, gambar, sinyal atau simbol.
\end{abstract}

Kata Kunci: PENGERTIAN STRUKTUR DATA 


\section{A. PENDAHULUAN}

struktur data adalah cara penyimpanan, penyusunan dan pengaturan data di dalam media penyimpanan komputer sehingga data tersebut dapat digunakan secara efisien.

Dalam teknik pemrograman, struktur data berarti tata letak data yang berisi kolom-kolom data, baik itu kolom yang tampak oleh pengguna (user) atau pun kolom yang hanya digunakan untuk keperluan pemrograman yang tidak tampak oleh pengguna.

\section{B. TINJAUAN PUSTAKA}

(PUTRA, Arie Setya; FEBRIANI, Ochi Marshella. Knowledge. Management Online Application in PDAM Lampung Province. In: Prosiding International conference on Information Technology and Business (ICITB). 2018. P. 181-187.

Elvinaro, dkk, Komunikasi Massa Suatu Pengantar, (Bandung: Simbiosa, 2014), hlm 37.

C. STUDI KASUS

Mengetahui apa itu struktur data,cara penerapan struktur data,dan bagian bagian yang ada di struktur data

\section{. PENGERTIAN STRUKTUR DATA}

Dalam istilah ilmu komputer, sebuah struktur data adalah cara penyimpanan, penyusunan dan pengaturan data di dalam media penyimpanan komputer sehingga data tersebut dapat digunakan secara efisien.Sedangkan Data adalah representasi dari fakta dunia nyata. Fakta atau keterangan tentang kenyataan yang disimpan, direkam atau direpresentasikan dalam bentuk tulisan, suara, gambar, sinyal atau simbol.

Konstanta digunakan untuk menyatakan nilai tetap sedangkan variable digunakan dalam program untuk menyatakan nilai yang dapat berubah-ubah selang eksekusi berlangsung.

Ada empat istilah data, yaitu:

1. Tipe data adalah jenis atau macam data di dalam suatu variable dalam bahasa pemrograman. 
2. Objek data mengacu kumpulan elemen, $\mathrm{D}$ (domain).

3. Representasi data : Suatu mapping dari struktur data 'd' ke suatu set ke struktur data 'e' ( $d===e)$ misal bolean di representasikan dalam 0 dan 1.

4. Struktur data biasa dipakai untuk mengelompokan beberapa informasi yang terkait menjadi sebuah kesatuan.

Dalam teknik pemrograman, struktur data berarti tata letak data yang berisi kolom-kolom data, baik itu kolom yang tampak oleh pengguna (user) atau pun kolom yang hanya digunakan untuk keperluan pemrograman yang tidak tampak oleh pengguna.Setiap baris dari kumpulan kolom-kolom tersebut dinamakan catatan (record). Lebar kolom untuk data dapat berubah dan bervariasi. Ada kolom yang lebarnya berubah secara dinamis sesuai masukan dari pengguna, dan juga ada kolom yang lebarnya tetap. Dengan sifatnya ini, sebuah struktur data dapat diterapkan untuk pengolahan database (misalnya untuk keperluan data keuangan) atau untuk pengolah kata (word processor) yang kolomnya berubah secara dinamis. Contoh struktur data dapat dilihat pada berkas-berkas lembar-sebar (spreadsheet), pangkal-data (database), pengolahan kata, citra yang dipampat (dikompres), juga pemampatan berkas dengan teknik tertentu yang memanfaatkan struktur data.

Secara garis besar type data dapat dikategorikan menjadi:

\section{Type data sederhana.}

Type data sederhana tunggal, misalnya Integer, real, boolean dan karakter.

Type data sederhana majemuk, misalnyaString

\section{Struktur Data, meliputi:}

Struktur data sederhana, misalnya array dan record.

Struktur data majemuk, yang terdiri dari: 
a) Linier : Stack, Queue, sertaList dan Multilist

b) Non Linier : Pohon Biner dan Graph

Pemakaian struktur data yang tepat didalam proses pemrograman akan menghasilkan algoritma yang lebih jelas dan tepat, sehingga menjadikan program secara keseluruhan lebih efisien dan sederhana.

Struktur data yang standar yang biasanya digunakan dibidang informatika adalah:

$>$ List linier (Linked List) dan variasinya

Multilist

$>$ Stack (Tumpukan)

$>$ Queue (Antrian)

$>$ Tree (Pohon)

$>$ Graph (Graf)

\section{PEMBUATAN STRUKTUR DATA}

Untuk membuat menjadi struktur data, kita harus melakukan dulu aktivitas terhadap objek data, yaitu :

* Mendeskkripsikan kumpulan operasi sah yang diterapkan ke elemen-elemen objek data.

* Menunjukan mekanisme kerja operasi-operasi.

Objek data integer ditambah operasi $(+,-, *, /$, mod , cell , floor,$<,>)$ dan operasi-operasi lain yang memanipuasi objek data integer menyatakan struktur data.

Struktur data $=$ Objek data $+\{$ Operasi manipulasi $\}$.

Tahap pembuatan struktur data adalah :

$>$ Tahap pertama : Spesifikasi

Pendeskripsian / spesifikasi struktur data menyatakan apa yang dapat dilakukan struktur data, bukan cara penerapannya.

Spesifikasi dapat dilakukan dengan dua cara, yaitu : 
- Spesifikasi secara formal

- Spesifikasi secara informal

Tahap kedua : Implementasi

Implementasi menyatakan cara penerapan struktur data dengan struktur data yang telah ada.Implementasi struktur data adalah proses pendefinisian tipe data abstrak sehingga semua operasi dapat dieksekusi computer. Implementasi struktur penyinpanan item-item data serta algoritma-algoritma untuk implementasi operasi-operasi sehingga menjamin terpenuhinya karakteristik struktur data, relasi item-item data atau invariant pada struktur data itu.

$>$ Tahap ketiga : Pemrograman

Pemrograman terstruktur adalah penerjemahan menjadi pernyataan di bahasa pemrograman tertentu. Prosesnya terdiri dari :

- Deklarasi yang mendefinisikan objek-objek data dan hubungannya...

- Pembuatan prosedur / rutin untuk operasi-operasi dasar yang menjaga invariant pada struktur data itu .

Sesuai dengan relasi yang didefinisikan di spesifikasi perancangan harus memilih tipe-tipe data yang telah ada untuk merepresentasikan struktur data.

Struktur data di bangun menggunakan fasilitas pembentukan atau pembuatan struktur data yang disediakan bahasa seperti array, record, dan sebagainya atau yang telah di buat seperti stack, queue, atau himpunan menggunakan linked list.

Pembuatan struktur data adalah pembentukan tipe data lengkap yang mempunyai empat property berikut :

1. Nama : Identifier tipe data

2. Domain : Domain / himpunan semesta nilai di tipe data

3. Konstanta (penyebutan anggota-anggotanya) : Cara penyebutan anggotaanggota tipe data

4. Operasi-operasi terhadap tipe data itu (operator) : Daftar operasi 
terhadap anggota tipe data sehingga kelakuan objek data sesuai spesifikasi.

\section{KESIMPULAN}

Dapat di simpulkan bahwa struktur data adalah cara penyimpanan, penyusunan dan pengaturan data di dalam media penyimpanan komputer sehingga data tersebut dapat digunakan secara efisien. 


\section{E. REFERENSI}

[1] PUTRA, Arie Setya; FEBRIANI, Ochi Marshella. Knowledge Management Online Application in PDAM Lampung Province. In: Prosiding International conference on Information Technology and Business (IC/TB). 2018. P. 181187.

[2] FEBRIANI, Ochi Marshella; PUTRA, Arie Setya. Sistem Informasi Monitoring Inventori Barang Pada Balai Riset Standardisasi Industri Bandar Lampung. Jurnal Informatika, 2014, 13.1: 90-98

[3] Putra, A. S. (2018, July 9). 2018 Artikel Struktur Data, Audit dan Jaringan Komputer. Retrieved from osf.io/3uq8w

[4] Elvinaro, dkk, Komunikasi Massa Suatu Pengantar, (BAndung: Simbiosa, 2014), hlm 37. 